\title{
Comparative Analysis of Various Adsorbents used for Bioremediation of Copper from the Aqueous Environment
}

\author{
Akshaya Priyah ${ }^{1}$,Vignesh Kumar C ${ }^{2 *}$ \\ akshayapriyah2000@gmail.com,cvk.bio@psgtech.ac.in \\ Department of Biotechnology, PSG College of Technology, Peelamedu, Coimbatore 641004, India ${ }^{1}$
}

\begin{abstract}
Aqueous environments are facing many challenges.The most important challenge among them is the pollution due to heavy metals. These heavy metals which is left untreated in aqueous environments can cause profound impacts in all living creatures which is in contact with untreated water. Of many heavy metals, copper is found in large amount in aqueous environments. Therefore, a need arises to tackle this issue of copper contamination. There are various ways to remove heavy metals. Of these, bioadsorption is gaining more importance in removing heavy metals from aqueous environments due to its various advantages and its increased capacity of adsorbing copper ions. Bioadsorption is a surface phenomenon where the heavy metals are adsorbed to the adsorbent (biological material), thereby facilitating removal of heavy metal from aqueous environments. Biological material can include agricultural waste residues, microbial cells like fungi, yeast, bacteria, etc. The main focus of this study is to compare and review on various adsorbents used for removing copper based on its efficiency,cost of production and availability.
\end{abstract}

Keywords: Heavy metals, aqueous environments, copper, bioadsorption, adsorbents.

\section{Introduction}

Environmental pollution is one of the increasing problems that is found everywhere today. Both organic and inorganic pollutants are called as environmental pollutants. Organic pollutants can be degradable but inorganic pollutants like heavy metals cannot be degraded and so it continues to stay in environment for a long time and poses a serious threat not only to marine life but also to humans and other living creatures. Heavy metals include copper, lead, zinc, cadmium, chromium, arsenic, mercury etc. Of these, copper is the most widely used heavy metal. It can be released accidentally or due to human induced activities like mining or from a large number of electrical industries. It can also be from battery making industries, while performing copper electroplating, from copper smelting plants and other activities. This metal when released into aqueous bodies can become a part of food chain which can lead to bio magnification and can cause detrimental to living creature. The toxic nature of copper can causes various irritations in skin, affects the respiratory organ of fishes(gills),interferes in their smelling capacity which helps them to find food for them, etc. On an overall, it has the most tremendous and lethal effect on all life forms. 
TABLE 1 : MPC Standards of copper

\begin{tabular}{|c|c|c|c|}
\hline Element & $\begin{array}{l}\text { MPC in } \\
\text { water(mg/l) }\end{array}$ & $\begin{array}{l}\text { MPC }^{\text {a }} \quad \text { in } \\
\text { waste } \\
\text { waters }(\mathrm{mg} / \mathrm{l})\end{array}$ & $\begin{array}{l}\mathrm{MPC}^{\mathrm{b}} \text { in waste } \\
\text { waters }(\mathrm{mg} / \mathrm{l})\end{array}$ \\
\hline Copper & 0.1 & 1.0 & 0.1 \\
\hline
\end{tabular}

Copper consumption (Table 1) in high amounts can cause various disorders by forming various deposits in kidney,liver, brain and other vital organs in humans (Jaishankar et.al., 2014). Various techniques used in removing copper from aqueous environments includes precipitation, membrane separation, floatation, biosorption, adsorption, ion exchange (Fig. 1).

Fig. 1:Various mechanism of Biosorption:Biosorption can be done in many ways like ion exchange,chelation,surface adsorption,electrostatic interaction.

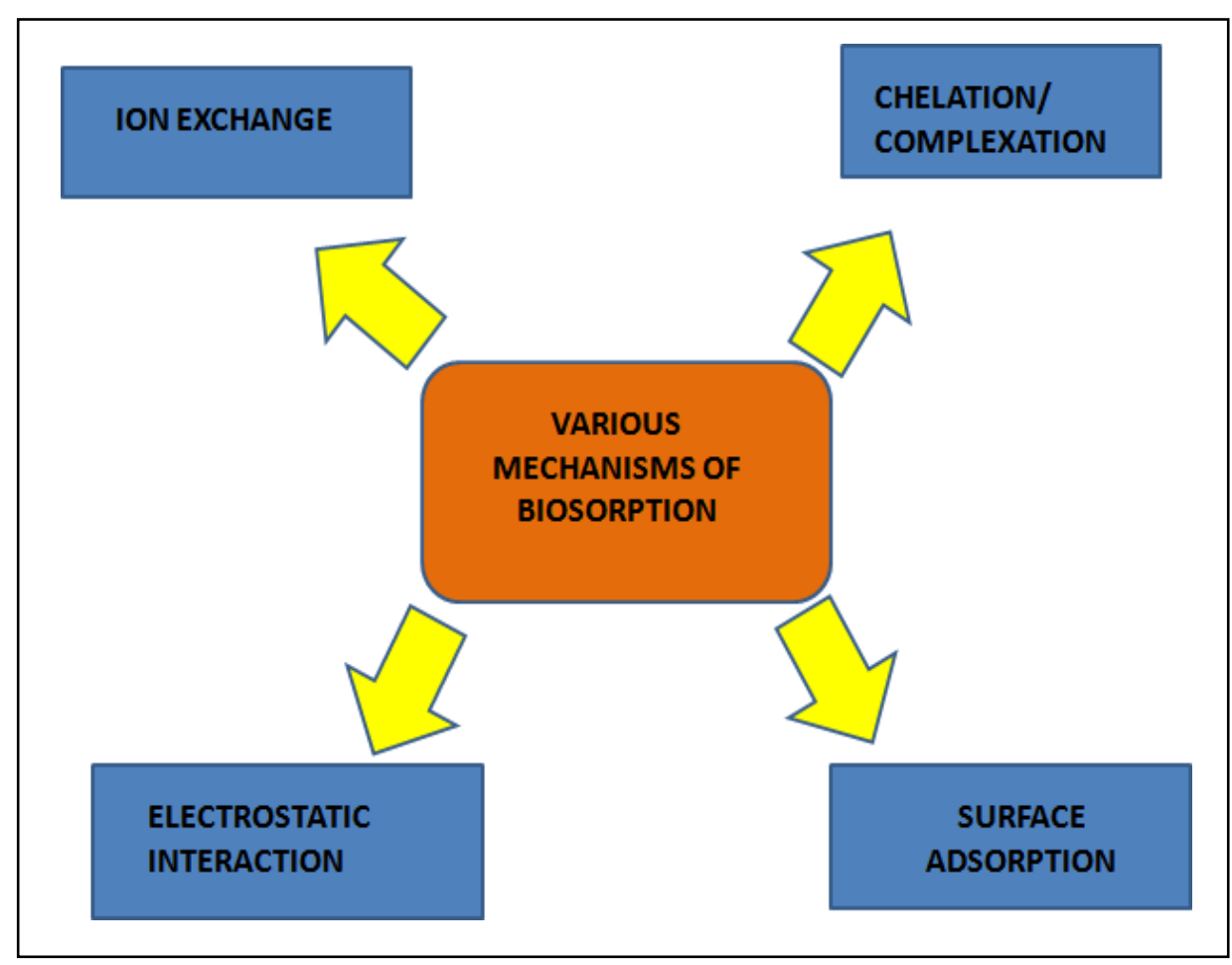


Fig. 2: Overview of Adsorption.

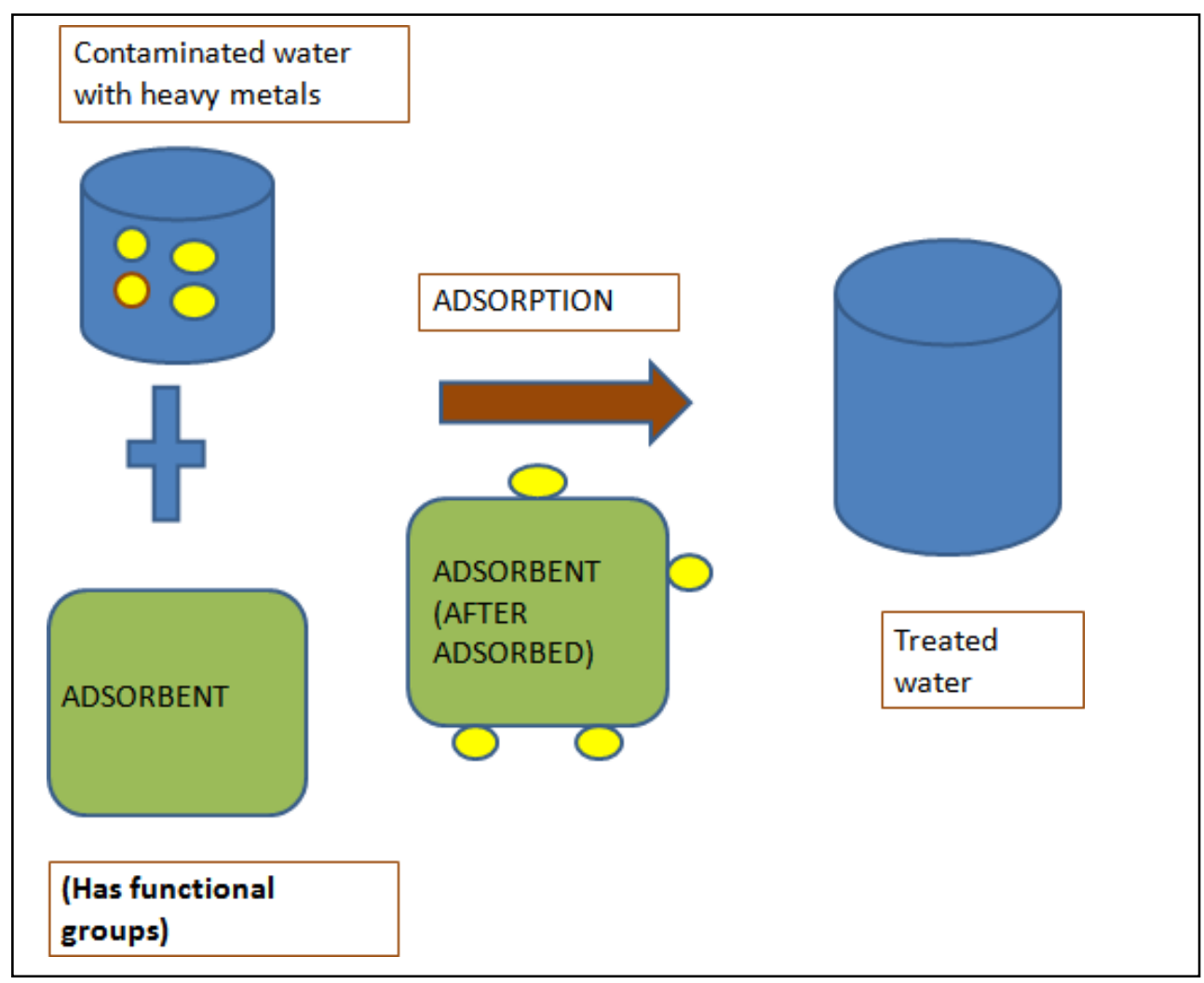

When heavy metals contaminated water is in contact with bioadsorbent, heavy metals gets adsorbed on these adsorbent as they contain suitable functional groups and aids in removing heavy metals from water.

Of these adsorption is most trusted method due to its various advantages. Adsorption is a process of removing pollutant from liquid environments using solid through either physical or chemical interactions (fig. 2). Adsorbents are substances to which the pollutant is being adhered to as a result of adsorption process. Different types of adsorbents are used in removing heavymetals. Adsorbents from various sources can be classified into natural based and microbial based adsorbents. Natural based adsorbents are adsorbents that are obtained from nature which is either treated or untreated and subjected for adsorption process (Ojedokun et.al., 2015 and Soumi et.al., 2021).Microbial based adsorbents are microbial cells like algae, mushroom, bacteria, etc. that are grown and used for adsorbing copper. 


\section{Natural based adsorbents}

Natural adsorbents are used in two ways. They are unmodified and modified adsorbents. Unmodified adsorbents are used as as such in adsorption process where as modified adsorbents were converted to certain form and then subjected to treatments of activation and adsorption process like activated carbon (O.Yavuz et.al., 2002 and Babel et.al., 2013).

\section{Unmodified Natural adsorbents}

Some of the unmodified natural adsorbents include zeolite, flyash, sawdust, dolomite, clays. These adsorbents since as they were not subjected to any treatment process showed very less efficiency in copper adsorption (Fig. 3).Even though certain minerals like dolomite, haematite,zeolites are porous in nature but they seem to exhibit poor adsorption and this seems that there is a need for a treatment to increase their adsorption capability (D.B.Singh,et.al., 1998).Natural dolomite was more efficient in adsorption than haematite which showed adsorption capacity of $0.244 \mathrm{mg} / \mathrm{g}$ only.Natural dolomite had a adsorption capacity of 1.02 $\mathrm{mg} / \mathrm{g}$. Among zeolites, haematites, flyash and natural dolomite,the zeolites showed more efficiency of adsorption of copper of $1.64 \mathrm{mg} / \mathrm{g}$. But,the adsorption efficiency of these adsorbents are very low when compared to other natural unmodified adsorbents like clay and saw dust.Saw dust showed a good adsorption efficiency of $13.8 \mathrm{mg} / \mathrm{g}$. Saw dust was more efficient in copper adsorption than clay which showed only $9.58 \mathrm{mg} / \mathrm{g}$ of adsorption of copper ions. Clay showed increased adsorption of copper ions than flyash. So, researchers wanted to increase these adsorbents efficiency of adsorption of copper ions, thus they subjected them to various modifications. The data of various adsorbents used without any modifications and their adsorption efficiencies are listed in table 2.

Table 2: Natural adsorbents and their modification

\begin{tabular}{|l|l|l|l|}
\hline $\begin{array}{l}\text { Name 0f the } \\
\text { adsorbent }\end{array}$ & $\begin{array}{l}\text { Nature of the } \\
\text { Modification }\end{array}$ & $\begin{array}{l}\text { Adsorption } \\
\text { efficiency(mg/g) }\end{array}$ & Reference \\
\hline Zeolite & Natural & 1.64 & Babelet.al., (2013) \\
\hline Clays & Natural & 9.58 & Abolinio et.al., (2003) \\
\hline fly ash & Natural & 1.39 & Panday et.al., (1985) \\
\hline Sawdust & Natural & 13.8 & Ajmalet.al., (1998) \\
\hline Haematite & Natural & 0.2444 & D.B.Singh et.al., (1998) \\
\hline natural dolomite & Natural & 1.02 & O.Yavuz et.al., (2002) \\
\hline Orange peel & $\begin{array}{l}\text { Interaction of } \\
\text { methyl acrylate }\end{array}$ & 289 & Feng et.al., (2009) \\
\hline $\begin{array}{l}\text { Rubber wood } \\
\text { sawdust }\end{array}$ & $\begin{array}{l}\text { activated with } \\
\text { phosphoric acid }\end{array}$ & 15.72 & Helenet.al., (2005) \\
\hline Alginate & $\begin{array}{l}\text { functionalized } \\
\text { with nano particles }\end{array}$ & 52.67 & Alina et.al., (2020) \\
\hline Flyash & treated with NaOH & 64 & Wanget.al., (2006) \\
\hline $\begin{array}{l}\text { Saccharomyces } \\
\text { cerevisease }\end{array}$ & Heat killed & 9.01 & Machado et.al., (2009) \\
\hline
\end{tabular}




\begin{tabular}{|l|l|l|l|}
\hline soyhulls & $\begin{array}{l}\text { Base extracted } \\
\text { followed by citric } \\
\text { acidmodification }\end{array}$ & 154.90 & Wartelle et.al., (2000) \\
\hline
\end{tabular}

Fig 3:Types of adsorbents used in adsorption process of heavy metals.

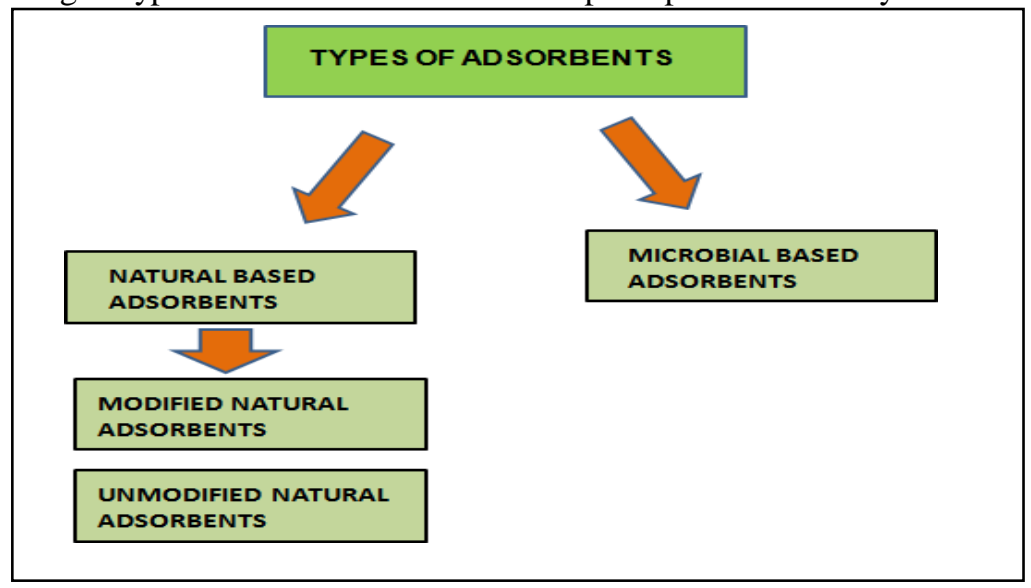

\section{Modified natural adsorbents}

Since naturally available unmodified adsorbents showed very poor adsorption capacity of copper of less than $20 \mathrm{mg} / \mathrm{g}$, to increase their capacity of adsorption towards copper,they were subjected to various modifications.Mostly the adsorbents were converted into activated carbon and they were subjected to acidic or alkaline treatments for its enhancement. This type of modified adsorbents showed little more efficiency in adsorbing copper. Since by chemical treatment,we are imparting functional groups that interacts and binds to copper ions. The flyash when used without any treatments gave only an adsorption efficiency of $1.39 \mathrm{mg} / \mathrm{g}$ but when they were treated with sodium hydroxide, the adsorption of copper increased from 1.39 to $64 \mathrm{mg} / \mathrm{g}$ (Wang et.al, 2007). This is due to that sodium hydroxide imparted negatively charged hydroxyl groups making the molecule to bind it to positively charged copper ions. When the saw wood of rubber is used, only $13.8 \mathrm{mg} / \mathrm{g}$ of copper adsorption was accounted but when they were subjected to phosphoric acid treatment,it showed increase in adsorption of copper from 13.8 to $15.72 \mathrm{mg} / \mathrm{g}$ (Helen Kalavathy et.al,2006). Clay showed adsorption efficiency of 9.58 but when it is activated via hydrochloric acid treatment, it showed 83.3 $\mathrm{mg} / \mathrm{g}$ in adsorbing copper.

Modification of the adsorbents are done by imparting negatively charged groups like carboxyl's (citric acid)or hydroxyl's or phosphate(phosphoric acid) etc.Citric acid modified adsorbents showed increased adsorption towards copper when compared to other treatments (BoZhuet.al., 2008 and L.H.Wartelleet.al., 2000.) since a molecule of citric acid gives three carboxyl groups thus facilitating increased adsorption.One such example of citric acid modified adsorbent is soyhulls. Soyhulls are cheap source of raw material for adsorption. Despite this, India is the fourth largest producer of soybeans, this gives an idea of large availability of soyhulls. And these soyhulls when base extracted and subjected to citric acid,it showed an enormous increased adsorption of copper that is $154 \mathrm{mg} / \mathrm{g}$. This citric acid modified 
soyhulls also has an adsorption towards other heavy metal like lead,zinc. Thus due to its vast availability in the country, low cost of raw material,capacity of adsorbing various heavy metals on its surface makes soyhull a good candidate to remove aqueous environments that are contaminated with heavy metals via adsorption.Orange peel showed a good increased adsorption of copper when they were cross linked with methyl acrylate.It showed adsorption capacity of $289 \mathrm{mg} / \mathrm{g}$. The adsorption capacity of chemically modified orange peel was more efficient then citric acid modified soyhulls. When iron nanoparticles are functionalized with alginate particles, it showed copper adsorption capacity of $52.67 \mathrm{mg} / \mathrm{g}$. But this capacity of adsorption of copper ions was much lower than the adsorption capacity of citric acid modified soyhulls and chemically modified orange peel.Iron nanoparticles functionalized with alginate was more efficient than soyhull based alginate bioadsorbent.The information of various modified adsorbents, their adsorption capacity of copper and the strategy used for adsorption of copper are mentioned in table 2.

\section{Microbial adsorbents}

After natural modified and unmodified types of adsorbents, the most popular adsorbent that was appreciated are the microbial adsorbents.Generally microorganisms play an important role in removing various contaminants present in polluted environments. Various people also identified the effective potential of different microbial cells in adsorbing the copper ion which is found in contaminated environments. The adsorption of copper by microbial cells was possible since the surface of microbes have some charged groups on it ,for example,bacteria cell wall contains various anionic functional groups (carbonyl groups, amine group, sulfhydryl group, phosphoryl group) enabling adsorption or if the microbes had poor surface charge groups, it is enhanced by subjecting it to treatments (Wayne E. Marshall et.al., 1995).

Bacteria are one of the unicellular organisms and prokaryotes that had been exploited for studying the adsorption capacity of copper.Bacteria are very small in size and had the capacity to grow in different environmental conditions.Based on the cell wall of bacteria,bacteria was categorized into gram positive and gram negative bacteria.The cell wall of bacteria had various negatively charged functional groups like carboxyl,amino, phosphoryl and various sulfhydryl groups. These negatively charged group interacts with positively charge copper ion and thus facilitation the adsorption of copper ions to the surface of bacteria.

Gram positive bacteria showed increased adsorption of copper compared to gram negative bacteria since gram positive bacteria had a very thick peptidoglycan layer and other glycoproteins facilitating more adsorption of copper towards its surface.On the other hand,Gram negative bacteria exhibited less adsorption of copper on its surface due to presence of thin layered peptidoglycan and presence of less glycoproteins (Navarre et.al., 1999).Bacillus.sp showed more efficiency in adsorbing copper ions than gram negative E.coli species and Pseudomonas putida. The Bacillus sp had an adsorption capacity of $16.3 \mathrm{mg} / \mathrm{g}$ (Salman et.al., 2015 and Bilal et.al., 2013).But this adsorption capacity of bacteria was very much lower than certain modified natural adsorbents. Some of the adsorption capacities of bacterial bioadsorbent are mentioned in table 3 .

TABLE 3: Microorganism Based adsorbents

\begin{tabular}{|l|l|l|l|}
\hline $\begin{array}{l}\text { Types of } \\
\text { microbial cell }\end{array}$ & Adsorbent & $\begin{array}{l}\text { Adsorbent } \\
\text { efficiency }\end{array}$ & Reference \\
\hline
\end{tabular}




\begin{tabular}{|c|c|c|c|}
\hline \multirow{3}{*}{ Bacterial } & Bacillus $s p$ & 16.3 & Salman et.al., (2015) \\
\hline & Escherichia coli & 5.86 & Bilal et.al., (2013) \\
\hline & Pseudomonas putida & 8 & Salman et.al., (2015) \\
\hline \multirow{14}{*}{ Algae } & Spirogyra(green algae) & 133 & Gupta et.al., (2006) \\
\hline & Eckloniasp & 90 & Feng and Aldrich(2004) \\
\hline & Ulva Lactuca & 52.1 & Cochrane et.al., (2006) \\
\hline & Turbinariaormate & 104.2 & Cochrane et.al., (2006 ) \\
\hline & Fucusvesiculosus & 114 & Cochrane et.al., (2006 ) \\
\hline & $\begin{array}{l}\text { Callithamnion } \\
\text { corymbosum }\end{array}$ & 47.62 & Alina et.al., (2020) \\
\hline & Chlorella & 33.4 & Maznahet.al., (2012) \\
\hline & Codiumvermilara & 16.52 & Romeraet.al., (2007) \\
\hline & Gelidium & 31.37 & Vilaret.al., (2007) \\
\hline & Cystoseiracrinitophylla & 160 & Christofordiset.al., (2015) \\
\hline & Sargassum sp. & 71.4 & Jacinto et.al., (2009) \\
\hline & Chlorococcum & 19.3 & Jacinto et.al., (2009) \\
\hline & Padina sp. & 50.87 & Kaewsarn P. (2012) \\
\hline & gracillaria sp. & 72.44 & Sheng et.al., (2008) \\
\hline \multirow{9}{*}{ Fungi } & $\begin{array}{l}\text { Flammulina } \\
\text { velupties }\end{array}$ & 8.13 & Lia et.al., (2018) \\
\hline & $\begin{array}{l}\text { Auricularia } \\
\text { polytricha }\end{array}$ & 6.04 & Liaet.al., (2018) \\
\hline & Pleurotuseryngii & 4.29 & Liaet.al., (2018) \\
\hline & $\begin{array}{l}\text { Pleurotus } \\
\text { ostreatus }\end{array}$ & 5 & Liaet.al., (2018) \\
\hline & $\begin{array}{l}\text { Schizophyllum } \\
\text { commune }\end{array}$ & 1.52 & Veit et.al., (2005) \\
\hline & Aspergillus niger & 26 & Gautam et.al., (2014) \\
\hline & Rhizopusoryzae & 19.4 & Bilalet.al., (2013) \\
\hline & Mucorruoxii & 52.2 & Bilalet.al., (2013) \\
\hline & $\begin{array}{l}\text { Trametes } \\
\text { versicolor }\end{array}$ & 60.98 & Sahanet.al., (2010) \\
\hline
\end{tabular}

Algae are very large in terms of their size in comparison to bacteria,thus providing a large surface for high adsorption capacity of copper. The capacity of binding to metal ions in algae is similar to bacteria,as algae cell wall also contains negatively charged functional groups.Algae are found in multiple environments. Different types of algae do exists.They are green algae which is also sometime called as micro algae.There are brown algae which is most called as marine algae or popularly known as brown algae and there is also red algae that can be found in environments.Among various microbial cells exploited for adsorption of copper, the algae showed the more efficient copper adsorption.From various data collected,it was seen that brown algae type of algal species showed more adsorption towards copper(Alina Roxana 
Lucaciet.al., 2020).Some of the examples of green algae include chlorella and spirogyra.Spirogyra species of algae showed more efficient copper adsorption than chlorella. Among various macro algae, Turbunariaormate macro algae showed more efficient copper adsorption than other species of macro algae like Ulva, Lactuca and Fucusvesiculosus sp (E.L. Cochrane et.al.,2006). The Cystoseira species showed increased adsorption towards copper than Spirogyra and Cystoseira species showed adsorption capacity in the range of $160 \mathrm{mg} / \mathrm{g}$ (Christofordis,et.al.,2015)

Fungi are also one of the microbial cells that showed adsorption towards copper. Fungi include mushroom,yeasts,molds.Cell wall of fungi contains chitin,mannans, glucans and various other lipids.They also have various anionic functional groups like sulfhydryl groups,carboxyl groups, amino groups, etc. Various species of fungi showed different adsorption capacity based on their presence of functional groups in it.Fungi also showed good amount of copper binding capacity (Sahanet.al.2010,).

Even both live and dead fungi was able to bind to copper but the active fungal cells showed more copper uptake since it was actively involved in metabolizing copper. Dead fungal cells were rarely preferred since it lacks metabolizing capacity and only the functional groups present in its surface renders it adsorption capacity. Overall,the adsorption capacity of fungi was much less than algae.But few fungal species showed good adsorption capacity of copper than few bacterial species.

\section{Modification Strategies of natural adsorbents and alternate adsorbents}

There are various strategies through which adsorbent can be modified to increase its adsorption efficiency (fig. 4).Some of the most widely used are mentioned here. They include acidic and basic treatments of adsorbents, using various biopolymers, nanoparticles functionalized with various functional groups. When adsorbent is subjected to mineral acids like hydrochloric acids, phosphoric acids showed a good result on adsorption of copper in few adsorbents.Organic acids can also be used to enhance the adsorption of copper. An example to it is citric acid. (M. Helen Kalavathy et.al,2005). Sodium carbonate, sodium hydroxide treatment has also proven to increase the adsorption capacity of copper being adsorbed to the surface of the adsorbent. (Wanget.al,2007). Notable examples of base treated adsorbents are wheat straw,flyash.

Fig 4:Strategies of modifying adsorbents.

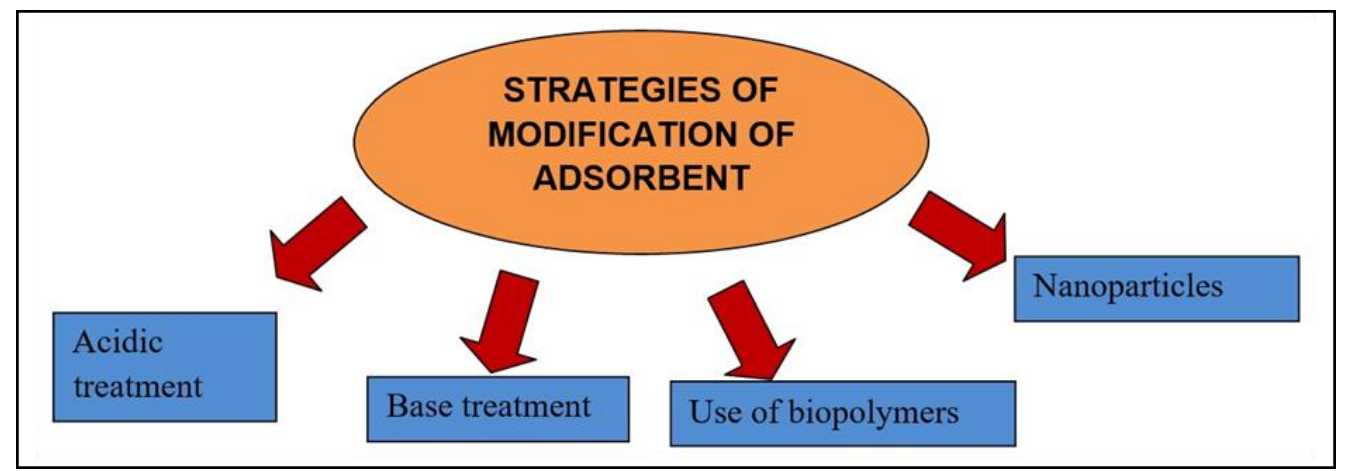


The use of Biopolymers by grafting suitable biopolymers on the surface of adsorbent will facilitate efficient adsorption of copper since biopolymers contain negatively charged functional groups thereby enhancing the binding of positively charged copper ions (Fenget.al., 2009).Nanoparticles also showed increased adsorption towards copper due to their high surface area to volume ratio. Iron nanoparticles functionalized with alginate particles act as the effective adsorbent of copper from an aqueous environment (Alina Roxana Lucaci et.al., 2020).

\section{Conclusion}

Despite the existence of different methods like precipitation, ion exchange, precipitation, Flocculation in removing copper from aqueous environments. Each adsorbent had its own limitations. Some of the methods generate a large amount of sludge. Some processes involve huge costs for its production process. But adsorption can be one of the best techniques through which adsorption of copper and other heavy metals can be removed from an aqueous environment. It can be exploited for making use of different adsorbents that are very low in cost like agricultural waste materials and possess some advantages like they are largely available,easy to recover metals once they are adsorbed and these metals once recovered can be used for other purposes.

A large number of agricultural waste materials are available across the country especially in North India wherein regions like Punjab,Haryana and other areas where they practice stubble burning which involves the burning of agricultural waste materials and this leads to air pollution. So, these leftover agricultural wastes in fields can be made as a useful source by making these as an adsorbent of copper with the help of suitable modifications. Because, using agricultural products,its modified form showed more adsorption towards copper. This implies that pre-treatment can enhance the adsorption capacity of adsorbent, thus helping the efficient removal of copper from polluted environments. Using adsorbents directly without any modification showed poor efficiencyof adsorption of copper as seen in table 1.Modification enhances the adsorption of copper towards the adsorbent. Modification is done by using various mineral acids (like hydrochloric acid)or organic acid (like citric acid) or treating with base (like $\mathrm{NaOH}$ ). Among these, citric acid is used for the modification for surface features of adsorbent showed more adsorption because they contained more negatively charged groups thus interacting with positively charged copper ion and facilitating removal of copper ion from contaminated aqueous environments. Agricultural based adsorbents has also certain limitations, it requires more cost for its production as it involves modification and they can't uptake various heavy metals at a time. On comparing various adsorbents for copper, microbial based adsorbents showed increased levels of adsorption. Microbial based adsorbents has more advantages and they are used for a wide range of conditions. The cost of production involved will be much less. Microbial based adsorbents can be used for various heavy metal uptake at a time. There is no need for chemical additions. A large quantity of contaminated water can also be easily treated by using microbes as adsorbents. On the other hand, the chemicals used for desorption of copper from microbial adsorbents should be cautiously selected or else it would affect the surface features of microbes. Algae cells exhibited increased high copper adsorption when compared to other microbial cells like bacteria, fungi and yeasts. By analyzing various adsorbents, it can be found that the interaction occurring between the surface of an adsorbent and the metal ion forms complexes and removes the contaminant. Of the various microbial 
cells used for adsorption, algal species exhibited more adsorption due to their large surface and presence of more anionic ligands. Of various species of algae, marine algae (macroalgae) showed good adsorption of copper.There is always a need for a novel adsorbent. Continuous improvement is needed from the existing adsorbents because resources available are not enough to adsorb copper efficiently from aqueous environments, new absorbents can be discovered through studying and analysing its surface properties and then by making modifications/pre-treatments would enhance copper removal from the environment and reduce heavy metal toxicity.

\section{References}

[1] Abollino O., Aceto M., Malindro, M Sarzanini, E Menatste, (2003), Adsorption of heavy metals on Na-montmorillonite: Effect of pH and organic substances, Water Research,37:5, 1619- 1627.

[2] Ajmal M., Khan A H., Ahmad S. and Ahmad, (1998) ,A. Role of sawdust in the removal of copper (II) from industrial wastes, Water Res. 32, 3085.

[3] Alina Roxana Lucaci, DumitruBulgariu, Maria-Cristina Popescu, and Laura Bulgariu, (2020), Adsorption of $\mathrm{Cu}(\mathrm{II})$ Ions on Adsorbent Materials Obtained from Marine Red Algae Callithamnioncorymbosumsp.,MDPI,Water, 12, 372.

[4] Bilal Muhammad, Ali Shah Jehanzeb, Ashfaq Tayyab, Mubashar Hussain Gardazi Syed, Ahmad Tahir Adnan, Pervez Arshid, Haroon Hajira, Mahmood Qaisar, (2013), Waste Biomass adsorbents for copper removal from industrial wastewater-A review,Journal of Hazardous Materials,263:322-333.

[5] Bozhu,TongxiangFan, DiZhang, (2008), Adsorption of copper ions from aqueous solution by citric acid modified soybean straw, Journal of Hazardous Materials 153:300-308.

[6] Christoforidis A., Orfanidis S., Papageorgiou S., Lazaridou A., Favvas E., Mitropoulos A. (2015), "Study of $\mathrm{Cu}(\mathrm{II})$ removal by Cystoseira crinitophylla biomass in batch and continuous flow biosorption." Chemical Engineering Journal, 277, 334-340.

[7] D B Singh, D C Rupainwar, G Prasad, K C Jayaprakash, (1998),Studies on the Cd (II) removal from water by adsorption, Journal of Hazardous materials, 6:1, 29-40.

[8] Dhiraj Sud,Garima Mahajan, M P Kaur, (2008), Agricultural waste material as potential adsorbent for sequestering heavy metal ions from aqueous solutions, Bio resource Technology ,99: 60176027.

[9] E L Cochrane, S Lu, S W Gibb, I Villaescusa,(2006),A comparison of low-cost bio sorbents and commercial sorbents for the removal of copper from aqueous media, Journal of hazardous materials, Volume- 137, issue-1,1, Pages 198-206.

[10] Feng D., C Aldrich. , (2004),Adsorption of heavy metals by biomaterials derived from marine algae Ecklonia maxima,Hydrometallurgy,73:1-2:1-10.

[11] Feng Ningchuan., Xueyi Guo., ShaLiang ,(2009),Adsorption study of copper (II) by chemically modified orange peel, Journal of Hazardous Materials, 164:2-3:1286-1292.

[12] Gautam RavindraKumar., AckmezMudhoo. , Lofrano, Mahesh., (2014), Biomass derived bioadsorbents for metal ions sequestration: Adsorbent modification and activation methods and adsorbent regeneration,Journal of environmental chemical engineering. 2:239-259.

[13] GuptaV K,Rastogi A.,Saini V K.,Jain,(2006),Biosorption of copper(II)ion from aqueousSolutions using spirogyra species, Journal of Colloid interface in Science, 296:59-63.

[14] HasanTekin Sahan, Ceylan,NurettinSahiner, NahitAktas, (2010), Optimization of removal conditions of copper ions from aqueous solutions by Trametesversicolor,BioresourceTechnology,101:12, 520-4526.

[15] Helen M. Kalavathy, T Karthikeyan, SRajgopal, Lima Rose Miranda,, (2005), Kinetic and Isotherm Studies of $\mathrm{Cu}$ (II) Adsorption ontoH3PO4-activated Rubber Wood Sawdust, journal of colloid and interface surface, $292: 2,354-62$

[16] Jaishankar, Monisha, Tseten, Tenzin, Anbalagan, Naresh, Mathew, Blessy B. and Beeregowda, Krishnamurthy N. (2014) "Toxicity, mechanism and health effects of some heavy metals" Interdisciplinary Toxicology, 7:2, ,60-72. 
[17] Kaewsarn P (2002). Biosorption of copper(II) from aqueous solutions by pre-treated biomass of marine algae Padina sp. Chemosphere, 47(10):1081-5.

[18] Lia, X., Zhanga, D., Sheng, F., Qing, H., (2018). Adsorption characteristics of Copper (II),

[19] Zinc (II) and Mercury (II) by four kinds of immobilized fungi residues, Ecotoxicol.

[20] Environ. Saf. 147, 357-366.

[21] Machado MD, Janssens S, Soares HM, Soares EV (2009), Removal of heavy metals using a brewer's yeast strain of Saccharomyces cerevisiae: advantages of using dead biomass. J. Appl. Microbiol. 106(6):1792-804.

[22] Maria Lourdes J.A.J. Jacinto, Carlos Primo C. David, Teresita R. Perez, Benjamin R. De Jesus,(2009), Comparative efficiency of algal bio filters in the removal ofchromium and copper from wastewater, Ecological engineering, 35(1):856-860.

[23] Maznah W.O. Wan, Al-Fawwaz A.T., Surif Misni (2012), Biosorption of copper and zinc by immobilised and free algal biomass, and the effects of metal biosorption on the growth and cellular structure of Chlorella sp. and Chlamydomonas sp. isolated from rivers in Penang, Malaysia, Journal of Environmental Sciences, 24:8,1386-1393.

[24] Navarre, W. W., \& Schneewind, O. (1999). Surface proteins of gram-positive bacteria and mechanisms of their targeting to the cell wall envelope. Microbiology and molecular biology reviews : MMBR, 63(1), 174-229.

[25] Ojedokun Adedamola Titi and Olugbenga Solomon Bello, (2015), An Overview of Low Cost Adsorbents for Copper (II) Ions Removal, J Biotechnol Biomater 5:177.

[26] Panday K.K., Gur Prasad, V.N. Singh, (1985), Copper (II) removal from aqueous solutions by fly ash,Waterresearch,19(7):869-873

[27] L.H Wartelle, W.E Marshall, (2000),Citric acid modified agricultural by-products as copper ion adsorbents,Advances in Environmental Research,4(1):1-7.

[28] Romera E., González F., Ballester A., Biazquez M.L., Munoz J.A.(2007),Comparative study of biosorption of heavy metals using different types of algae, Bioresource Technology,98:17, 3344 3353.

[29] Salman, Muhammad, Athar, Makshoof,Farooq, Umar (2015), Biosorption of heavy metals from aqueous solutions using indigenous and modified lignocellulosic materials, Reviews in Environmental Science and Biotechnology. 14(2):211-228.

[30] Sandhya Babel, TonniAgustionoKurniawan (2003), Low-cost adsorbents for heavy metals uptake from contaminated water: a review.Journal of Hazardous Materials, 97(1-3): 219-243.

[31] Soumi Dutta, Bramha Gupta, Suneel Kumar Srivastava and Ashok Kumar Gupta (2021) Recent advances on the removal of dyes from wastewater using various adsorbents: a critical review, Mater. Adv., 2, 4497-4531.

[32] Veit Marcia Teresinha, Tavares Celia Regina Granhen, Gomes-da-Costa Sandra Maria, Guedes Terezinha Aparecida (2005), Adsorption isotherms of copper(II) for two species of dead fungi biomasses, Process Biochemistry, 40:10, 3303-3308.

[33] Vilar VJ, Botelho CM, Boaventura RA (2008). Copper removal by algae Gelidium, agar extraction algal waste and granulated algal waste: kinetics and equilibrium. Bioresour Technol. 99(4):750-62.

[34] Wang S, Li L, Zhu ZH (2007), Solid-state conversion of fly ash to effective adsorbents for $\mathrm{Cu}$ removal from wastewater. J Hazard Mater. 10;139(2):254-9.

[35] Wayne E. Marshall \& Elaine T. Champagne,(1995), Agricultural by products as adsorbents formetal ions in laboratory prepared solutions and in manufacturing wastewater, Journal ofEnvironmental Science and Health,30: 241-261.

[36] Yavuz Omer, YalcinAltunkaynak, Fuat Guzel,(2003),Removal of copper, nickel, cobalt and manganese from aqueous solution by kaolinite, Water Research,37(4):948-952. 